\title{
MicroRNA and cancer: a focus on mammary tumors in female dogs
}

\author{
Rosana Lino Salvador-Bernabé ${ }^{\circ}$ Mirela Tinucci-Costa ${ }^{1}$ Renee Laufer Amorim ${ }^{2 *}$
}

${ }^{1}$ Departamento de Clínica Veterinária e Cirurgia, Universidade Estadual Paulista Julio de Mesquita Filho (UNESP), Jaboticabal, SP, Brasil. ${ }^{2}$ Departamento de Clínica Veterinária, Faculdade de Medicina Veterinária e Zootecnia (FMVZ), Universidade Estadual Paulista (UNESP), Botucatu, SP, Brasil. E-mail: renee.laufer-amorim@unesp.br. "Corresponding author.

ABSTRACT: Mammary tumors are the most frequent tumors reported in female dogs and have great relevance in veterinary oncology; however, little is known about the molecular mechanisms involved in the development of metastasis. An increasing number of human studies have suggested that epigenetic alterations, such as DNA methylation, miRNA, and histone modifications, are the predominant events leading to the metastatic phenotype in tumor cells and participate in regulating oncogenic signals associated with tumor spread. Among these epigenetic alterations, miRNAs have stood out in recent years, presenting a fundamental role in tumorigenesis. There are still few studies evaluating the role of miRNAs in canine mammary tissues. Thus, this paper aims to review the role of miRNAs in cancer with a special focus on canine mammary tumors.

Key words: oncology, dog, mammary carcinoma, miRNA.

MicroRNA e o câncer: um enfoque em tumores mamários de cadelas

RESUMO: Os tumores mamários caninos são considerados os mais frequentes em cadelas, além de apresentarem grande relevância na oncologia veterinária, porém a doença metastática ainda é um desafio que compreende mecanismos moleculares não totalmente esclarecidos. Um número crescente de estudos na medicina humana tem sugerido que alterações epigenéticas, tais como metilação do DNA e modificação das histonas são eventos predominantes na célula tumoral para aquisição do fenótipo metastático, participando da regulação de sinais oncogênicos associados com a disseminação do tumor. Dentre as alterações epigenéticas, os miRNAs se destacaram nos últimos anos apresentando um papel fundamental na tumorigênese. Ainda existem poucos estudos avaliando o papel dos miRNAs em tecidos mamários caninos. Assim, com este trabalho objetiva-se revisar o papel dos miRNAs no câncer com foco especial nos tumores de mama de cadelas. Palavras-chave: oncologia, cão, carcinoma mamário e miRNA.

\section{INTRODUCTION}

MicroRNAs (miRNAs) correspond to a class of small, single-stranded RNAs with an average length of 17 to 25 nucleotides. They originate from non-protein-coding regions (introns) and play a role in post-transcriptional gene regulation under normal physiological conditions, being essential in tissue differentiation, cellular cycle, proliferation, and apoptosis (REDDY, 2015). Currently, 453 mature miRNAs have been identified in the canine genome (miRBase database, last updated in February 2018, <http://www.mirbase.org/cgi$\mathrm{bin} /$ browse.pl?org $=\mathrm{cfa}>$ ), and similarities between miRNA expression in human and canine cancer have been described (WAGNER et al., 2013).

Several mechanisms may lead to altered miRNA expression, including genomic alterations, such as amplifications, deletions, mutations, polymorphisms, epigenetic changes, and alterations in miRNA biogenesis. These alterations may be responsible for deregulating miRNA expression levels or for changing miRNA target genes in tumor cells (CALIN et al., 2004).

A single miRNA can simultaneously regulate hundreds of genes, presenting high regulatory potential and disrupting a miRNA may affect the transcription of several genes that affect cancer-related signaling pathways (REDDY, 2015).

The stability of miRNAs makes them potential molecules for molecular studies since they are more stable than messenger RNA (mRNA). Therefore, miRNA expression may be easier to quantify in representative samples, such as tissues obtained from surgery or biopsy and formalin-fixed, paraffin-embedded tissues for anatomical pathological analysis (HU et al., 2010). 
Some studies have already reported differential miRNA expression by comparing tumor cells with normal cells. In some types of cancer, specific miRNAs have differential expression depending on tumor stage, from carcinogenesis to invasion and metastasis. miRNAs may act on oncogenes as well as tumor suppressor genes, contributing to tumoral formation in both cases (DI LEVA et al., 2014; REDDY, 2015).

Therefore, considering the relevance of miRNAs in neoplastic development, their potential role as therapeutic targets, and the increasing number of studies in this field, the present paper reviews the roles of miRNAs in cancer with a focus on canine mammary tumors.

\section{MmicroRNA biogenesis}

miRNA biogenesis occurs in the cell nucleus where it is transcribed, then the miRNA is exported to the cytoplasm and subsequently processed and matured. The microRNAs are singlestranded molecules derived from the transcription of genes present in DNA and are usually transcribed from introns or non-coding regions by the RNA polymerase II enzyme, which produces primary miRNA (pri-miRNA) with a cap structure in the 5' end and a poly(A) tail in the 3' end (KIM et al., 2009).

The pri-miRNA is cleaved in the nucleus by RNAse III (Drosha enzyme) and its cofactor, DiGeorge syndrome critical region gene 8 (DGCR8), resulting in one or more microRNA precursors called pre-miRNAs. These usually have strands 70 to 90 nucleotides in length and a secondary, non-paired structure (hairpin) that is loop-shaped. After this step, the pre-miRNA is recognized by the exportin-5' protein, which transports it to the cytoplasm, where a second RNAse III (Dicer enzyme) cleaves the region containing the hairpin, and a double-stranded miRNA is then processed (comprising the mature single-stranded miRNA and its complementary strand) with nearly 22 nucleotide pairs that will bind to the Argonaute (Ago) protein (DI LEVA et al., 2014; REDDY, 2015).

One of the miRNA strands is recognized by a protein complex called RNA-induced silencing complex (RISC). The strands are separated and the mature miRNA is incorporated into RISC, which pairs with imperfect complementarity to messenger RNA, resulting in inhibited translation or degradation of the target mRNA. The post-transcriptional regulatory mechanism relies predominantly on the interaction between miRNA and the 3' untranslated region (3'-UTR) of the targeted mRNA, leading to the degradation or translation inhibition of the mRNA (DI LEVA et al., 2014; REDDY, 2015).

\section{MicroRNAs and cancer}

One of the first studies reporting the relationship between miRNAs and human tumorigenesis demonstrated that miR-15a and miR-16 are located at $13 \mathrm{q} 14$, a typical deletion region associated with neoplastic cells of lymphocytic leukemia in humans. This finding was associated with the loss of BCL2 gene expression, which plays an anti-apoptotic role in cells such as lymphocytes (CALIN et al., 2005). That study and other studies have shown that miRNAs are usually located in fragile sites: regions containing genomic gains or losses involved in cancer (CALIN et al., 2004; GARZON et al., 2009).

Global miRNA expression profiling is useful to differentiate between normal and neoplastic tissue, to identify the primary tissue of metastasis, and to distinguish different histological subtypes of tumors or determine associations to specific genetic disorders (IORIO \& CROCE, 2012). For example, the first miRNA profiling study in human breast cancer identified a signature of 15 miRNAs that could differentiate breast cancer from normal breast tissues with $100 \%$ accuracy (IORIO et al., 2005). BLENKIRON et al. (2007) also observed abnormal expression of 133 miRNAs in tumoral breast tissue compared to expression in normal tissue.

In human breast cancer, it has been demonstrated that miRNA regulates cell cycle progression, apoptosis, angiogenesis, epithelialmesenchymal transition, tumor microenvironment, migration, invasion, metastasis, and resistance to treatment, as well as differentiation and self-renewal of breast cancer stem cells (LI et al., 2012). For example, another study observed that a specific group of miRNAs was differentially expressed between basal and luminal breast cancer subtypes in women and was used to accurately determine estrogen, progesterone receptor-positive, and/or HER2/neu-positive tumors (IORIO et al., 2005; IORIO \& CROCE, 2012).

\section{MicroRNAs in canine cancer}

Studies evaluating miRNAs in different tumors in dogs are still scarce (NOGUCHI et al., 2013; GRIMES et al., 2016; STARKEY et al., 2017; KOBAYASHI et al., 2017). A recent study described a miRNA profile associated with metastasis in canine uveal melanoma by comparing eight metastatic tumors with 10 non-metastatic tumors using the Affymetrix miRNA 3.1 platform. A total of 14 differentially expressed miRNAs were identified, with two miRNAs (cfa-miR-155 and cfa-miR-182) confirmed by real time quantitative PCR (RT-qPCR) (STARKEY et al., 2017). 
Another study evaluated the global miRNA expression profile in melanoma using a microarray and validated 26 samples of oral melanoma and 11 samples of normal oral mucosa in dogs using RT-qPCR; miR$520 \mathrm{c}-3 \mathrm{p}$ expression was increased and the expression of miR-126, miR-200a, miR-203, miR-205, miR$517 \mathrm{~b}$, and miR-713 was decreased in the tumor group compared with that in the normal tissue group. In addition, the authors observed that the decrease of miR-203 and miR-205 expression occurred in human and canine cell lines, and that decreased miR-203 expression was associated with a shorter survival time. Furthermore, miR-205 re-expression significantly inhibited the cell growth of canine and human melanoma cells. Lastly, their data suggests that miR203 may constitute a new prognostic factor in canine oral melanoma, and that miR-205 acts as a tumoral suppressor through targeting the $E R B B 3$ gene in canine and human melanoma cells (NOGUCHI et al., 2013).

Recently, expression levels of mature microRNAs (miRs) from prostatic lesions in dogs were evaluated by comparing a non-tumoral group with a tumoral group using RT-qPCR. Five miRs (miR-18a, miR-95, miR-221, miR-222, and miR-330) exhibited increased expression levels; however, 14 miRs (miR-127, miR-148a, miR-205, miR-299, miR-329b, miR-335, miR376a, miR-376c, miR-379, miR-380, miR-381, miR-411, miR-487b, and miR-495) were negatively regulated and were related with prostatic adenocarcinoma. The authors suggested that these miRs may be potential markers for the early detection of prostatic adenocarcinoma and might be used in the future for miR-based therapy (KOBAYASHI et al., 2017).

Another study compared miRNA expression profiles among splenic hemangiosarcoma, splenic nodular hyperplasia, and normal splenic tissues in dogs using RNA sequencing. They used five samples from each group and reported 22 differentially expressed miRNAs in the hemangiosarcoma samples (4 miRNAs were differentially expressed between hemangiosarcoma, nodular hyperplasia, and normal spleen; and 18 were differentially expressed between hemangiosarcoma and normal spleen). More specifically, miR-26a, miR-126, miR-139, miR-140, miR-150, miR-203, miR-424, miR-503, miR-505, miR-542, miR-30e, miR-33b, miR-365, miR-758, miR-22, and miR452 were the miRs of interest in hemangiosarcoma pathogenesis (GRIMES et al., 2016).

\section{MicroRNAs in canine mammary tumors}

Studies on miRNAs in canine mammary tumors are scarce, particularly regarding metastatic progression (BULKOWSKA et al., 2017). Few studies have investigated the global miRNA expression profile in in vitro models of canine breast cancer (KRÓL et al., 2014; LUTFUL et al., 2015; OSAKI et al., 2016). Some studies evaluated miRNA expression in different phases of tumorigenesis using canine breast tissue and reported several differentially expressed miRNAs (BOGGS et al., 2008; VON DEETZEN et al., 2014; BULKOWSKA et al., 2017).

A study based on miRNA expression profiles in in vitro models of canine breast cancer investigated miRNA expression in a co-culture of canine mammary tumor cells with tumor-associated macrophages and observed changes in expression patterns, suggesting that the tumor microenvironment may affect miRNA expression (KRÓL et al., 2014).

Another study assessed the miRNA expression profiles in three canine mammary carcinoma cell lines, using an RT-qPCR platform with 277 canine miRNAs (cfa-miRNAs); 41 miRNAs showed increased expression and 24 showed decreased expression in the three lineages. Among these, miR141 was confirmed to regulate the tumor suppressor gene $I N K 4 A$ in two cell lines with increased miR-141 expression (LUTFUL et al., 2015).

A more recent study evaluated the miRNA profile in a canine mammary carcinoma cell line compared with normal canine mammary tissue and observed 291 miRNAs with altered expression; among them, miR-143 and miR-138a showed increased and decreased expression, respectively, in the cell line under study (OSAKI et al., 2016).

The miRNA profiles were also investigated in canine mammary carcinoma stem-like cells (stem cell antigen-1-, Sca-1-, CD44-, and EpCAMpositive) obtained by cell sorting from three canine mammary carcinoma cell lines. Twenty-four miRNAs with decreased expression and nine with increased expression were detected in those cell cultures compared with expression in well-differentiated tumor cells. Additionally, miRNA target prediction and signaling pathway analysis identified the TGF- $\beta$ pathway as potentially altered (RYBICKA et al., 2015).

To our knowledge, there are only three miRNA studies assessing canine mammary carcinoma tissues. Using RT-qPCR, one study assessed levels of ten miRNAs (miR-15a, miR-16, miR-17-5p, miR21, miR-29b, miR-125b, miR-145, miR-155, miR$181 \mathrm{~b}$, let-7f) that were previously reported to be associated with human breast cancer, from six samples of malignant mammary tumors and 10 normal tissue samples, and observed increased miR-21 and miR$29 \mathrm{~b}$ expression in tumors. The authors also observed a 
significant decrease of miR-15b and miR-16 expression in ductal carcinoma samples (BOGGS et al., 2008).

Another study assessed miRNAs associated with metastatic progression in canine mammary tissue by evaluating 16 miRNAs that were relevant in human breast cancer in 10 samples from normal canine breast, 10 adenoma, 10 metastatic mammary carcinoma, five lymph node metastasis, and 10 non-metastatic carcinomas. Increased miR-210 expression was detected in all tumors when compared to normal mammary tissues. The decreased expression of miR-29b, miR-101, miR-125a, miR-143, and miR-145 was observed in the metastases compared to the other groups, but the study failed to identify an miRNA potentially associated with metastasis progression (VON DEETZEN et al., 2014).

A study assessed the global miRNA expression profile in 146 samples of canine mammary tumors, including 30 benign samples, 116 malignant samples, and 25 normal breast samples to test the metastatic progression associated with 317 miRNAs. The data was confirmed by real time PCR for 10 miRNAs (let-7c, miR-10b, miR-26a, miR-26b, miR-29c, miR-30a， miR-29a，miR-29a， miR-30b, miR-30c, miR-148a, and miR-299), and the target genes were subsequently validated (CDC6, CCNE1, MYBL2, PDCD10, ERBB2IP, SON, STK4, CDC27, PRC1, CDC37, TTK, SKIL, BUB3, and SPIN1). In addition, four miRNAs (miR-144, cmiR-32, miR374a, and miR-1246) from samples of female dog plasma with non-metastatic breast tumor, metastatic breast tumor, and without tumor were validated; however, the authors were not able to confirm the association. Thus, they suggested that miRNAs mainly regulate the metastasis process but not the malignant transformation, and thus may be molecular markers of metastases (BULKOWSKA et al., 2017).

\section{Clinical applicability of miRNAs and future perspectives}

Advances in the understanding of cancer biology may promote the development of specific targeted therapies with the aim of blocking deregulated molecular pathways in tumor cells. This type of treatment, which is particularly more developed in human cancer, aims to selectively act on tumor cells; therefore, reducing the cytotoxicity associated with conventional chemotherapy and its collateral effects.

Considering that miRNAs regulate the expression of multiple target genes and are associated with deregulated molecular mechanisms in cancer, they may constitute promising treatment strategies (KASINSKI \& SLACK, 2011). Depending on a miRNA's function in the tissue and its expression in the tumor, it may be possible to develop miRNA-based therapies either by using miRNA-mimetic or antagonist agents (KASINSKI \& SLACK, 2011). Antagonist molecules may be used to inhibit or sequester miRNAs with increased expression, whereas mimetic molecules may be used to restore miRNAs with loss of function or decreased expression (BADER et al., 2011).

It has been suggested that miRNAs may be key modifiers of chemo-resistance and as promising therapeutic targets in human breast cancer (TANG et al., 2012; CAMPOS-PARRA et al., 2017). BOCKHORN et al. (2013) reported that high levels of miR-30c make breast cancer cells more sensitive to paclitaxel and doxorubicin treatment in preclinical models.

In a pioneering study into the use of miRNA inhibitors in cancer, MA et al. (2007), observed increased miR-10b expression in metastatic breast cancer and demonstrated that positive miR regulation may confer potential for metastasis formation in nonmetastatic breast cancer cell lines. Subsequently, MA et al. (2010) assessed this finding in mice and demonstrated that therapy using intravenous delivery of miR-10b antagomiR derivative inhibitor considerably inhibited lung metastasis; however, a reduction in primary tumor size was not observed.

In another study, ectopically increasing miR-621 expression promoted apoptosis and increased the chemo-sensitivity to paclitaxel and carboplatin treatment in breast tumor cells in vitro and in a xenograft tumor model. The FBXO11 gene was also found to be a direct target of miR-621 and its expression level was negatively correlated with $F B X O 11$ expression in breast cancer patients (XUE et al., 2016).

Like any other drug class, the efficacy and safety of miRNA-derived drugs should be carefully assessed and should rely on preclinical studies, cellular context, and preexisting genetic and epigenetic damage (ASIAF et al., 2018).

\section{CONCLUSION}

Considering the high incidence of mammary neoplasia in female dogs observed in veterinary care, and the relevance of miRNAs in processes associated with tumorigenesis, we reviewed the role of miRNAs in cancer with a special focus in mammary neoplasia in female dogs, describing results obtained in studies conducted on this species.

\section{REFERENCES}

ASIAF, A. et al. MicroRNA and Cancer. New York, NY: Springer New York, 2018. V. 1699.

Ciência Rural, v.48, n.11, 2018. 
BLENKIRON, C. et al. MicroRNA expression profiling of human breast cancer identifies new markers of tumor subtype. Genome Biology, 2007. v. 8, n. 10, p. R214. Available from: <http:// genomebiology.biomedcentral.com/articles/10.1186/gb-2007-810-r214>. Accessed: Nov. 11, 2017. doi: 10.1186/gb-2007-8-10-r214.

BOCKHORN, J. et al. MicroRNA-30c inhibits human breast tumour chemotherapy resistance by regulating TWF1 and IL-11. Nature Communications, 2013. v. 4, p. 1393. Available from: <https:// www.nature.com/articles/ncomms2393>. Accessed: Jan. 7, 2018. doi: $10.1038 /$ ncomms2393.

BOGGS, R. M. et al. MicroRNA expression in canine mammary cancer. Mammalian Genome, 2008. v. 19, n. 7-8, p. 561-569. Available from: $<$ http://link.springer.com/10.1007/s00335-008-9128-7>. Accessed: Nov. 26, 2017. doi: 10.1007/s00335-008-9128-7.

BULKOWSKA, M. et al. MicroRNA expression patterns in canine mammary cancer show significant differences between metastatic and non-metastatic tumours. BMC Cancer, 2017. v. 17, n. 1, p. 728. Available from: <https://bmccancer.biomedcentral.com/ articles/10.1186/s12885-017-3751-1>. Accessed: Mar. 7, 2018. doi: $10.1186 / \mathrm{s} 12885-017-3751-1$.

CALIN, G. A. et al. A MicroRNA Signature Associated with Prognosis and Progression in Chronic Lymphocytic Leukemia. New England Journal of Medicine, 2005. v. 353, n. 17, p. 1793 1801. Available from: <http://www.nejm.org/doi/full/10.1056/ NEJMoa050995\#t=articleTop $>$. Accessed: Nov. 26, 2017. doi: 10.1056/NEJMoa050995.

CALIN, G. A. et al. Human microRNA genes are frequently located at fragile sites and genomic regions involved in cancers. Proceedings of the National Academy of Sciences, 2004. v. 101, n. 9, p. 2999-3004. Available from: <http://www.pnas.org/cgi/ doi/10.1073/pnas.0307323101>. Accessed: Nov. 26, 2017. doi: 10.1073/pnas.0307323101

CAMPOS-PARRA, A. et al. Micro-RNAs as Potential Predictors of Response to Breast Cancer Systemic Therapy: Future Clinical Implications. International Journal of Molecular Sciences, 2 jun. 2017. v. 18 , n. 6, p. 1182. Available from: $<$ http://www.mdpi.com/14220067/18/6/1182>. Accessed: Jan. 7, 2018. doi: 10.3390/ijms18061182.

CHEN, J. et al. Down-regulation of microRNA-200c is associated with drug resistance in human breast cancer. Medical Oncology, 2012. v. 29 , n. 4, p. 2527-2534. Available from: <http://link. springer.com/10.1007/s12032-011-0117-4>. Accessed: Jan. 7, 2018. doi: 10.1007/s12032-011-0117-4.

DI LEVA, G.; et al. MicroRNAs in Cancer. Annual Review of Pathology: Mechanisms of Disease, 2014. v. 9, n. 1, p. 287-314 Available from: <http://www.ncbi.nlm.nih.gov/pubmed/24079833>. Accessed: Aug. 27, 2017. doi: 10.1146/annurev-pathol-012513-104715.

GARZON, R.; et al. MicroRNAs in Cancer. Annual Review of Medicine, 2009. v. 60, n. 1, p. 167-179. Available from: $<$ http://www. annualreviews.org/doi/10.1146/annurev.med.59.053006.104707>. Accessed: Nov. 26, 2017. doi: 10.1146/annurev.med.59.053006.104707.

GRIMES, J. A. et al. A comparison of microRNA expression profiles from splenic hemangiosarcoma, splenic nodular hyperplasia, and normal spleens of dogs. BMC Veterinary Research, 2016. v. 12, n. 1, p. 272. Available from: <http://bmcvetres.biomedcentral.com/ articles/10.1186/s12917-016-0903-5>. Accessed: Nov. 26, 2017. doi: 10.1186/s12917-016-0903-5.
HU, Z.; et al. Serum microRNA signatures identified in a genomewide serum microRNA expression profiling predict survival of non-small-cell lung cancer. Journal of Clinical Oncology, 2010. v. 28 , n. 10, p.1721-1726.

IORIO, M. V. et al. MicroRNA Gene Expression Deregulation in Human Breast Cancer. Cancer Research, 2005. v. 65, n. 16, p. 7065-7070. Available from: <http://cancerres.aacrjournals.org/ lookup/doi/10.1158/0008-5472.CAN-05-1783>. Accessed: Jan. 7, 2018. doi: 10.1158/0008-5472.CAN-05-1783.

IORIO, M. V.; CROCE, C. M. microRNA involvement in human cancer. Carcinogenesis, 2012. v. 33, n. 6, p. 1126-1133. Available from: <https://academic.oup.com/carcin/article-lookup/ doi/10.1093/carcin/bgs140>. Accessed: Nov. 26, 2017. doi: 10.1093/carcin/bgs140.

KASINSKI, A. L.; SLACK, F. J. MicroRNAs en route to the clinic: progress in validating and targeting microRNAs for cancer therapy. Nature Reviews Cancer, 2011. v. 11, n. 12, p. 849-864. Available from: <http://dx.doi.org/10.1038/nrc3166>. Accessed: Nov. 26, 2017. doi: $10.1038 / \mathrm{nrc} 3166$.

KIM, V. N.; et al. Biogenesis of small RNAs in animals. Nature Reviews Molecular Cell Biology, 2009. v. 10, n. 2, p. 126-139. Available from: $<\mathrm{http} / / /$ www.nature.com/articles/nrm2632>. Accessed: Nov. 26, 2017. doi: $10.1038 / \mathrm{nrm} 2632$

KOBAYASHI, M. et al. MicroRNA expression profiling in canine prostate cancer. Journal of Veterinary Medical Science, 2017. v. 79, n. 4, p. 719-725. Available from: < https://www.jstage.jst.go.jp/ article/jvms/79/4/79_16-0279/_article>. Accessed: Nov. 26, 2017. doi: $10.1292 /$ jvms. $1 \overline{6}-0279$.

KRÓL, M. et al. Macrophages Mediate a Switch between Canonical and Non-Canonical Wnt Pathways in Canine Mammary Tumors. PLoS ONE, 2014. v. 9, n. 1, p. e83995. Available from: <http:// dx.plos.org/10.1371/journal.pone.0083995>. Accessed: Aug. 27, 2017. doi: 10.1371/journal.pone.0083995.

LI, L. et al. Regulation of breast cancer tumorigenesis and metastasis by miRNAs. Expert review of proteomics, 2012. v. 9, n. 6, p. 615-625. Available from: <http://www.ncbi.nlm.nih.gov/pubmed/23256672>. Accessed: Jan. 7, 2018. doi: 10.1586/epr.12.64.

LUTFUL K., F. M. et al. Altered microRNA Expression Profiles and Regulation of INK4A/CDKN2A Tumor Suppressor Genes in Canine Breast Cancer Models. Journal of Cellular Biochemistry, 2015. v. 116, n. 12 , p. 2956-2969. Available from: <http://doi. wiley.com/10.1002/jcb.25243>. Accessed: Nov. 26, 2017. doi: $10.3390 /$ vetsci3010001.

MA, L. et al. Tumour invasion and metastasis initiated by microRNA-10b in breast cancer. Nature, 2007. v. 449, n. 7163, p. 682-688. Available from: <http://www.nature.com/ doifinder/10.1038/nature06174>. Accessed: Nov. 26, 2017. doi: $10.1038 /$ nature 06174 .

MA, L. et al. Therapeutic silencing of miR-10b inhibits metastasis in a mouse mammary tumor model. Nature Biotechnology, 2010. v. 28, n. 4, p. 341-347. Available from: <http://www.ncbi.nlm.nih.gov/ pubmed/20351690>. Accessed: Nov. 26, 2017. doi: 10.1038/nbt.1618.

NOGUCHI, S. et al. MicroRNAs as tumour suppressors in canine and human melanoma cells and as a prognostic factor in canine melanomas. Veterinary and Comparative Oncology, 2013. v. 11, 
n. 2, p. 113-123. Available from: <http://doi.wiley.com/10.1002/ vco.306>. Accessed: Nov. 26, 2017. doi: 10.1002/vco.306.

OSAKI, T. et al. Establishment of a canine mammary gland tumor cell line and characterization of its miRNA expression. Journal of Veterinary Science, 2016. v. 17, n. 3, p. 385. Available from: $<$ http://www.ncbi.nlm.nih.gov/pubmed/26726024>. Accessed: Aug. 27, 2017. doi: 10.4142/jvs.2016.17.3.385.

REDDY, K. B. MicroRNA (miRNA) in cancer. Cancer cell international, 2 dec. 2015. v. 15 , n. 1, p. 38.Avaliable from: $<$ http:// www.ncbi.nlm.nih.gov/pubmed/25960691>. Accessed: Aug. 27, 2017. doi: 10.1186/s12935-015-0185-1.

RYBICKA A.; et al. Analysis of microRNA expression in canine mammary cancer stem-like cells indicates epigenetic regulation of transforming growth factor-beta signaling. Journal of Physiology and Pharmacology, 2015. v. 66, n. 1, p. 29-37.

STARKEY, M. P. et al. Metastasis-associated microRNA expression in canine uveal melanoma. Veterinary and Comparative
Oncology, 2017. n. March, p. 1-9. Available from: <http://www. ncbi.nlm.nih.gov/pubmed/28512868>. Accessed: Nov. 26, 2017. doi: $10.1111 /$ vco. 12315

VON DEETZEN, M.-C. et al. Malignancy Associated MicroRNA Expression Changes in Canine Mammary Cancer of Different Malignancies. ISRN Veterinary Science, 2014. v. 2014, p. 1-5. Available from: $<\mathrm{http} / /$ www.pubmedcentral.nih.gov/articlerender.fc gi?artid $=4060554 \&$ tool $=$ pmcentrez\&renderty e $=$ abstract $>$. Accessed: Aug. 27, 2017. doi: 10.1155/2014/148597.

WAGNER, S. et al. Comparison of non-coding RNAs in human and canine cancer. Frontiers in Genetics, 2013. v. 4, n. April, p. 1-9. Available from: <http://journal.frontiersin.org/article/10.3389/fgene.2013.00046/ abstract>. Accessed: Nov. 26, 2017. doi: 10.3389/fgene.2013.00046.

XUE, J. et al. MiRNA-621 sensitizes breast cancer to chemotherapy by suppressing FBXO11 and enhancing p53 activity. Oncogene, 13 jan. 2016. v. 35 , n. 4 , p. $448-458$. Available from: $<$ http://www. nature.com/doifinder/10.1038/onc.2015.96>. Accessed: Nov. 26, 2017. doi: 10.1038/onc.2015.96. 